\section{THE BUDDHA IMAGE IN THAILAND ${ }^{1}$}

\section{Kukdej Kantamara ${ }^{2}$}

\begin{abstract}
Buddha images bear traits that are indicative of the ethnicity of their creators. The Thai Buddha images have unique characteristics which vary according to times and regions. This paper discusses the development in the artistic styles of the Thai schools of Buddha images, the characteristics of each school and the factors that influence it such as ethnicity and current culture.
\end{abstract}

We cannot deny that, according to historians who have studied written documents and archeological remains in Pakistan, the Buddha image was made for the first time in history by Greek sculptors.
1 "The Buddha Image in Thailand" was published in Japanese for the Great Buddha Symposium, held on December 20, 2003 at Nara Citizen Hall, Todaiji Temple, Nara City, Japan. The paper was also presented at Osaka City University Campus on December 22, 2003.

${ }^{2}$ Assoc. Professor, Visual Arts Division, the Faculty of Fine and Applied Arts, Chulalongkorn University.

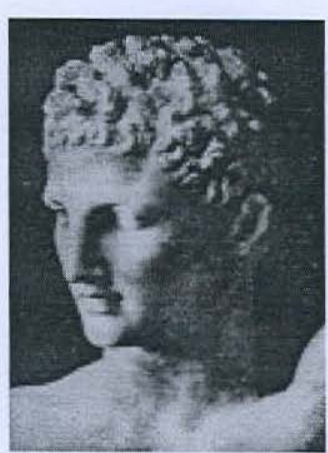

\section{God Apollo, Hellenistic period}

The Buddha's very first image was said to have been created in Gandhara around 600 B.E. after Alexander the Great invaded Northern India in 217 B.E.

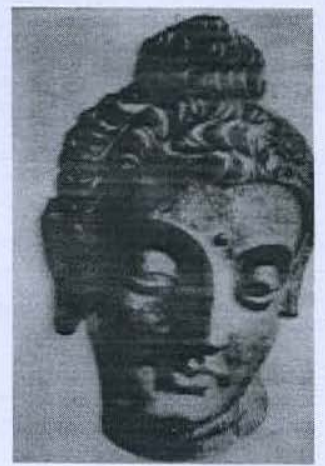

Buddha image by Greek sculptors

During the Greek invasion, Alexander's top army chiefs were sent to rule over the conquered land. When the king died, they wanted to become kings and fought with each other in hope of reigning over Gandhara, where most people were converted to Buddhism since the era of King Asoka the Great. 


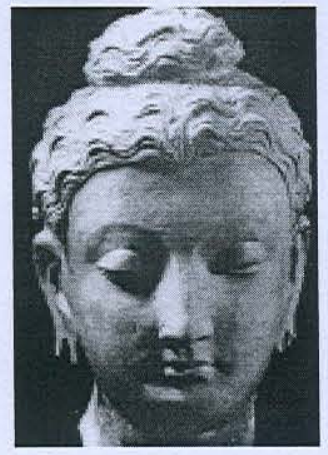

\section{Gandhara's Buddha image}

Then came a powerful monarch named Kanishka, who successfully united the entire Gandhara kingdom in 633 B.E. Having faith in the Buddhist religion, the king followed the footsteps of King Asoka the Great and took Buddhism under royal patronage in 688 B.E.

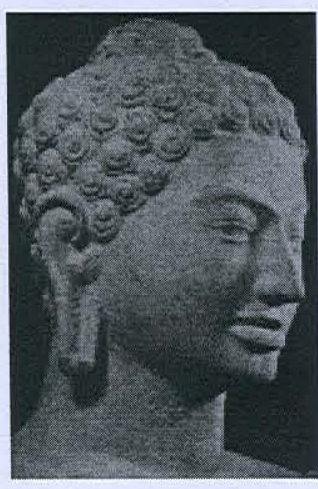

\section{Late Gandhara school with large hair curls}

Scholars believe that the first portrayal of the Buddha was made during his reign by Greek artists, who were already familiar with the sculptures of Greek gods and goddesses. The Buddha's statue was created with physical characteristics as recorded in the Mahapurisa Laksana text. Thus, it can be said that Buddha images appeared for the first time ever in the reign of King Kanishka.

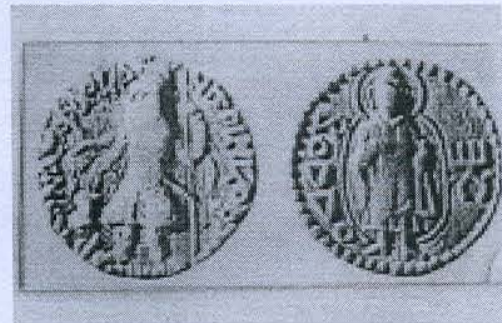

\section{Gold coin (AD.144-73) with King Kanishka on the obverse and the Buddha on the reverse}

After that, the creation of Buddha images became popular across India. The tradition also spread to countries in Indo-China, including Thailand.

The Kingdom of Thailand, formerly known as Suwannabhumi, or the Golden Land, was initially inhabited by Mon people who migrated from the Indian town of Dvaravati. Calling themselves "Dvaravit," they happily integrated with local people who dubbed themselves "Moon people", or "Mon" in the Thai language.

These peoples joined hands in establishing a great kingdom, with its capital in Nakhon Pathom province in the central region of modern-day Thailand. The city was named "Dvaravati" after the Indian evacuees' place of origin, which is now in Gujarat, India.

The peoples had become followers of the Buddha since the reign of Asoka the Great. The Indian king had sent two monks - Phra Uttarathera and Phra Sonathera - to propagate the religion in the land of Suwannabhumi long before the representation of the Buddha in human form. 
After the appearance of Buddha images, Indian monks brought with them smallscale Buddha icons to Suwannabhumi. Several bronze images of the Amaravati school, measuring 20 - 30 centimeters, have been found scattered in the region.

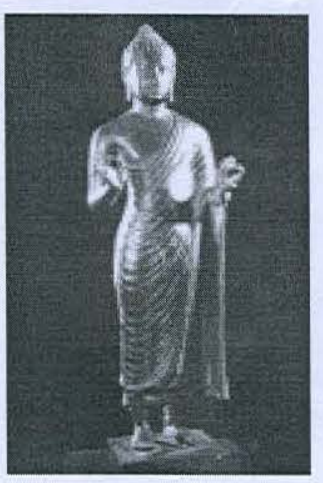

\section{0-30 C., the bronze images by Amaravati school}

However, no evidence has been found that Mon artists adopted the practice of Buddha representation, not until the coming of the Gupta school. Artists, copying Gupta art, began to create images in their Dvaravati style, which can be said to be the very first art school in Thailand.

However, a true Thai school had yet to appear. After the Dvaravati school came the Srivijaya and Lop Buri schools. It took some time before Thai Buddhist art developed as the Sukhothai, Chiang Saen, Ayutthaya, and Rattanakosin schools respectively.

\section{Before the Occupation of the Thai People?}

Thai artists adopted and applied Indian artistic traditions to create their own unique styles, while strictly keeping to the characteristics of the Buddha's physical appearance as indicated in the
Mahapurisa Laksana text. However, it is possible that the portrayal may bear some ethnic traits of their contemporary countrymen. Of course, that was unintentional on the artist's part - it all came naturally from the inside of his being.

Here are the cases in point. The Dvaravati school of the Mon people, which appeared during the $10-16^{\text {th }}$ Buddhist centuries, was in many ways similar to the Gupta school in terms of its characteristics and beliefs. Found in the central region of Thailand, most images of this period were made of stone, terra cotta (baked clay) and bronze. The remarkable characteristics include:

- $\quad$ Round head with plump cheeks

- Large hair curls

- Flat forehead

- Protruding eyes

- Eyebrows forming a continuous "crow's wings" curve

- Large and square face

- Thick lips

- Broad chin

- Thin robe clinging to the body

- Straight edged mantle or "sanghati" extending to the navel, or short sanghati hanging around the chest

- Large hands and feet

- Base carved into a lotus shape

- The Buddha sitting with legs extended and feet flat on the ground (Braramphabthasana)

- Aureole attached to the back of the head 


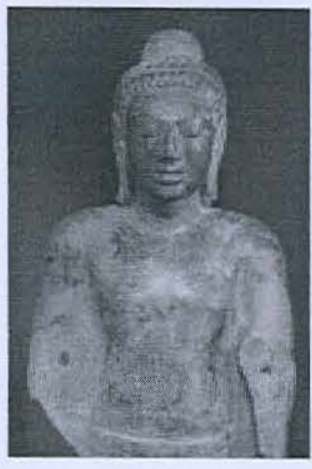

\section{Life - size stone of the Dvaravati school}

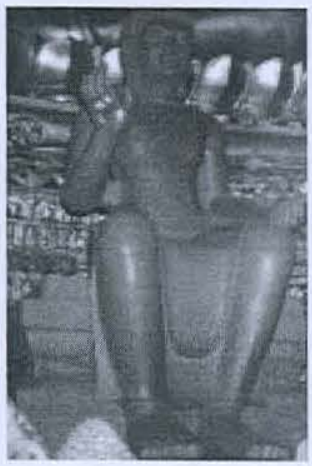

\section{Dvaravati Buddha sitting in Braramphabthasana posture, semi life-size, stone}

Another example is the Srivijaya school, which can be dated back to the $13-18^{\text {th }}$ Buddhist centuries. The term "Srivijaya" was coined by the renowned French archeologist George Coedes. Reading an ancient stone inscription at Wiang Temple in Chaiya district of Thailand's northern province of Surat Thani, the professor came across a text about Sri Wichayesuan Pubodi, the king who built three brick castles. There was also a record written by a Chinese monk called I Ching, who traveled to the region to study Buddhism in 1215 B.E. and mentioned a town called "Chilipochi."
Taking the two pieces of evidence into consideration, Professor Coedes believed that Srivijaya was part of the Sailentrawong kingdom, which extended over the islands around the Malay Peninsula.

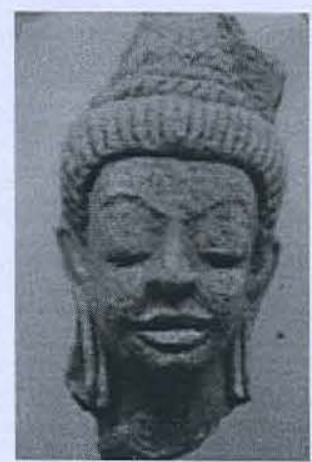

\section{Stone carving. Srivijaya school}

The Buddha images of the Srivijaya school were found largely in Chaiya district of northern Surat Thani province. Srivijaya art was influenced by the Buro Buddho School of Java and the Dvaravati and Pala-Sena Schools of southern India.

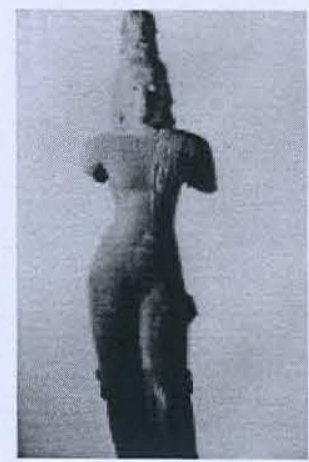

Avalokitesvara. Semi life-size, stone.

Initially, artists followed the Theravada tradition when creating Buddha images. They were later influenced by Mahayanist beliefs which came with the Pala school of art, thus resulting in the widespread popularity in sculpting 
representational portrayals of the Buddha's previous lives. However, Srivijaya sculptors were keen on mingling Pala traditions with their own to create a unique style whose delicacy and subtlety have significantly become its distinctive features.

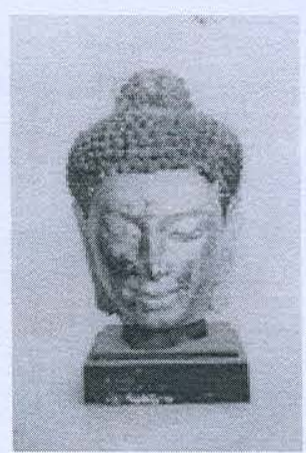

Srivijaya art was influenced by the Dvaravati school; life-size, stone, covered with gold leaf

You can see that the Buddha figure has a plump torso, with short hair curls in the shape of small conch shells. There is a mark between the eyebrows, and a Bodhi leaf is often seen on the topknot. The image has a flat forehead, arched eyebrows, round chin, and thin lips (usually with a gently smiling expression.) Now look at this bronze Avalokitesvara on your right hand side.

The masterpiece was believed to be in the contraposto (the right hip extending a little) with his right hand resting on the knee in "Granting a Boon" position, and the left hand stretching out to bear his weight. Wearing a crown with the Buddha Amitabha on it, the image has long braided hair extending to the navel. The upper torso is naked - covered with jewelry instead of an upper robe. Artists have long praised the image's beautiful face: the eyes cast downward express compassion, and the gentle smile signifies eternal blissfulness.

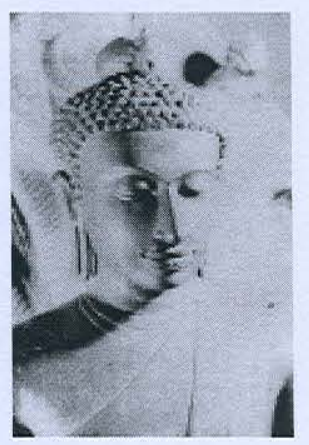

The Buddha image. The Srivijaya school, marked by a flat forehead, and a Bodhi leaf on the topknot, bronze life-size

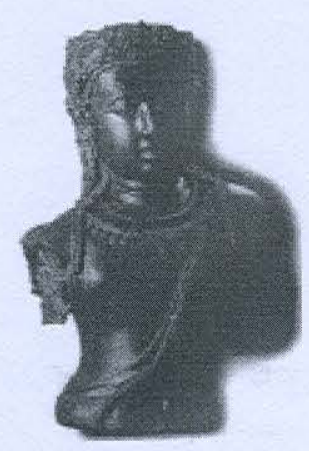

The masterpiece Avalokitesvara, bronze life-size 


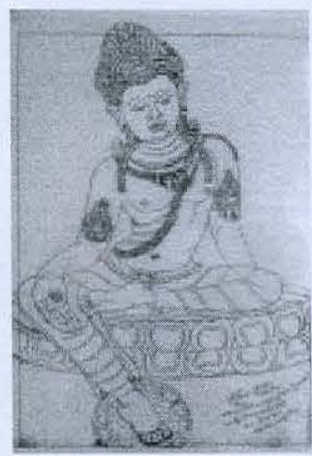

\section{The masterpiece Avalokitesvara in full gesture, as assumed}

The Lopburi school, dating from the 15$18^{\text {th }}$ century, was largely influenced by Mahayanist beliefs, which became prevalent with the Khmer dominion over central Thailand. Therefore, the Buddha images were a combination of both the Dvaravati school and Khmer art from Cambodia. As Lopburi was part of the Dvaravati kingdom, which later fell to the Khmer, the Buddhist art of this period was subsequently named Lopburi.

However, it is quite apparent that the Buddha images found in Lopburi had taken on Khmer traits only in their physical appearance and gestures. Other traits were left intact, especially reflecting the spirit of the nation. The Khmer style gives a stern and robust look while Lopburi art was much gentler and subtler.

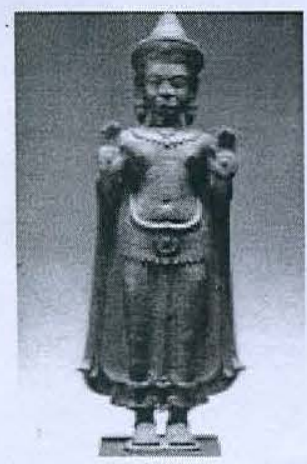

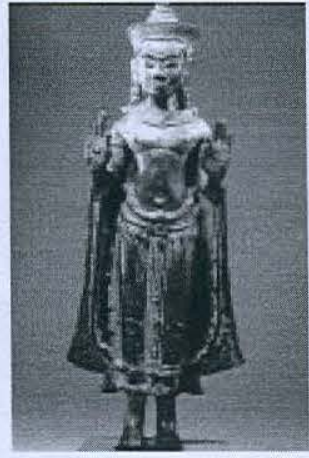

\section{The Buddha standing upright, Lopburi school}

Lopburi Buddha images can be characterized by a cranial protuberance with small shell-like thorns known in Thai as "Jackfruit Thorns." The head is decorated with a diadem and jewelry. The Buddha is often seen in a meditation posture, sitting on Naga's body, with Naga's 7 heads forming a protective canopy above his head.

The Buddha's facial features include a broad face, thick lips, broad chin, and earlobes that extend to the shoulder. Some images can be seen in the "Subduing Mara" posture wearing royal attire, which means the "Ahthit Buddhachao". The Naga Protected Buddha in Meditation Posture, holding a container of medicine in his hand, signifies the "Phisatchayaguru Buddha," the Buddha of healing. 

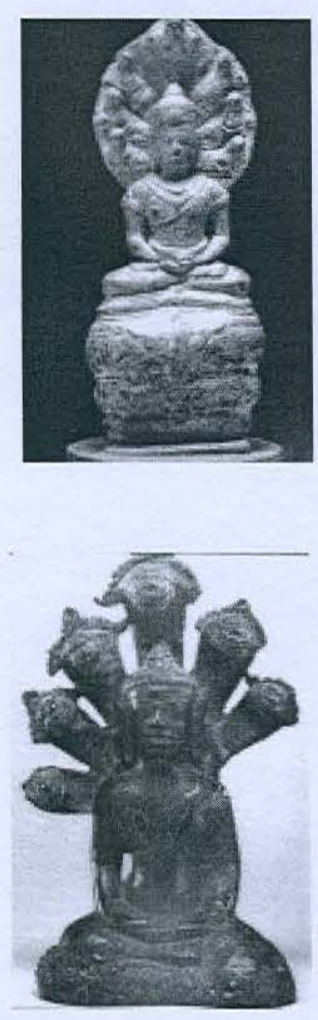

\section{The Naga Protected Buddha in Meditation Posture}

\section{After the Occupation of the Thai People?}

Thai people migrated from southern China and had their own language. But the creation of Buddha images didn't begin until Sukhothai was established as their very first sovereign kingdom in 1700 B.E. Their Buddhist art was heavily dominated by the Dvaravati and Lopburi schools due to political influence.

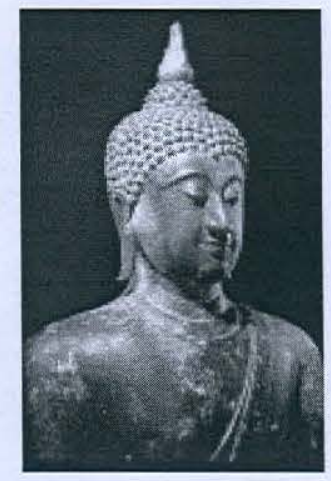

\section{Sukhothai Buddha image}

After Sukhothai's liberation from Khmer power, Thai sculptors tried to create Buddha images in their own way. The Pali Canon Council, coupled with Lankan Buddhist tradition, prompted the first Thai monarch of Sukhothai to send scholars to study in Sri Lanka. Upon their return, they brought back Buddhist knowledge and Sri Lankan art, which intricately fused with the local style.

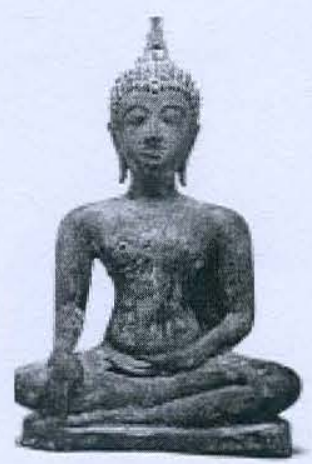

\section{Sukhothai Buddha influenced by Sri Lanka}

Art historians believe that before the coming of Lankan Buddhist tradition, Sukhothai Buddhist art was dominated by the Pala and Jola schools of India through Burma. This can be seen from the mark in the centre of the head called 
Unâlom, which typically belongs to the Jola school. It signifies "wisdom." Sukhothai artists adapted it in the form of a flame in motion. This signifies dynamism, which, in this context, means the Enlightenment of the Buddha.
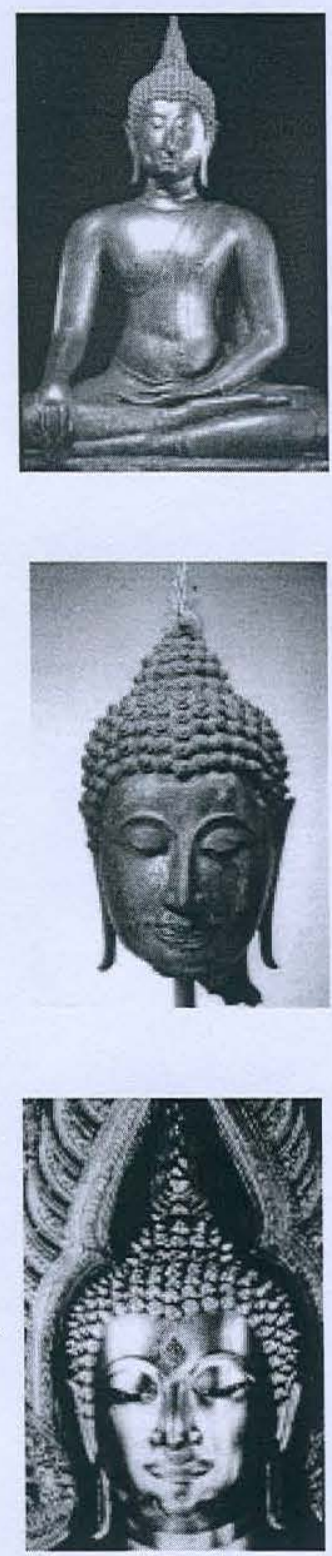

\section{Sukhothai Buddha influenced by} Pala school.

Unalom, which is typically in the form of a flame in motion
Sukhothai Buddha images are highly praised for their gracefulness and uniqueness. This was achieved through the use of metaphors and dancing art, coupled with the Buddha's characteristics as described in the Mahapurisa Laksana text. The Buddha's special marks include:

- Eyes like air passing a soaring bird

- Nose like a parrot's beak

For this bronze, life-size Walking Buddha, metaphors relating to a dancer's beauty were used, such as "arms like the trunks of young elephants," and "legs like an antelope's."

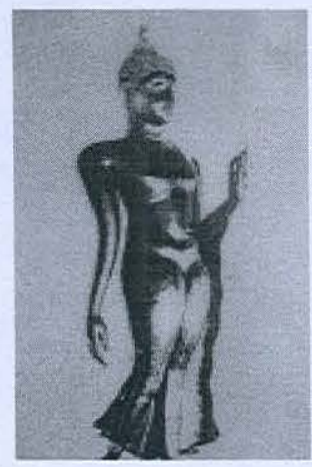

\section{Life-size Walking Buddha, "arms like the trunks of young elephants," and "legs like an antelope's"}

The reason Sukhothai Buddha images bear traits of feminine beauty was probably because women were the ones who commissioned the sculpting of the Buddha images. This can be seen from the inscription at the pedestal, saying that it was built to "substitute for her ordination," as women were not allowed to enter the monkhood. 

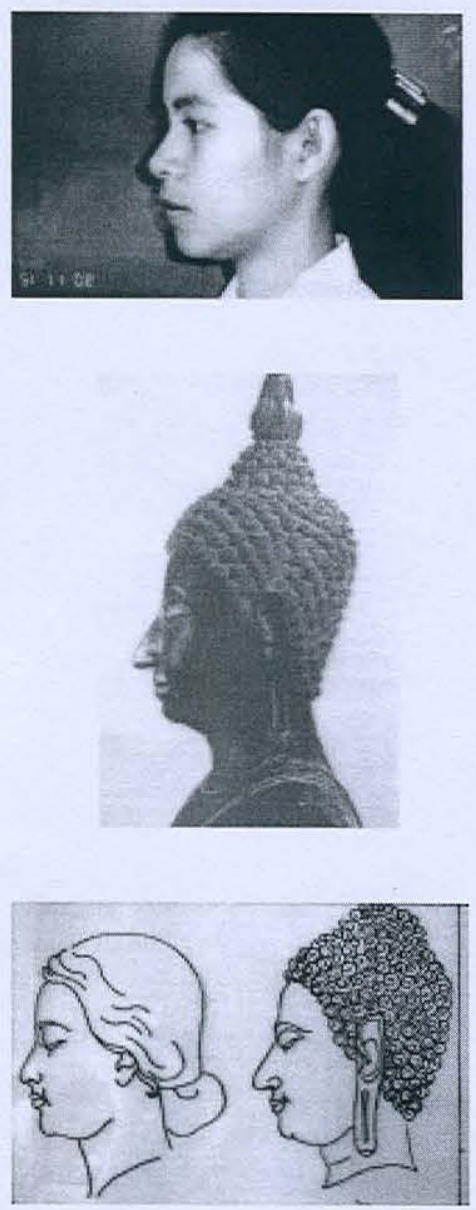

Buddha image bearing traits of feminine beauty

The divine characteristics of the Sukhothai Walking Buddha were achieved through the transformation of a realistic portrayal into an idealized one, while the use of perspective makes the movement happen lifelike. This is done by making the right shoulder and right thigh bigger than the left. With such skillful craftsmanship, Sukhothai artists can be said to have detached themselves from the Mahapurisa Laksana text. Instead, they proved to have clear understanding of perspective - just about the same time their Western counterparts were going through the Renaissance in another part of the world.

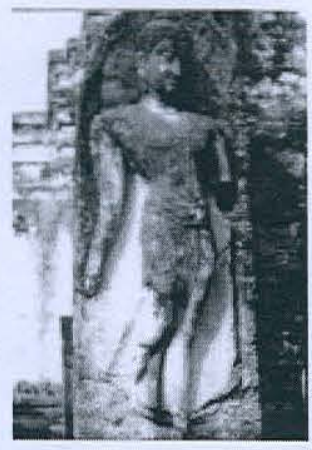

\section{The Sukhothai Walking Buddha}

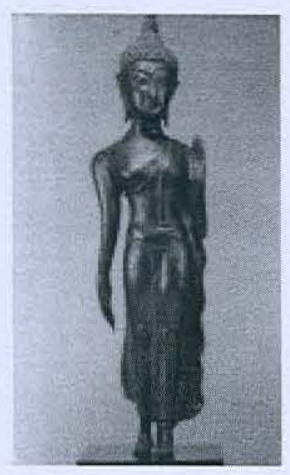

\section{Buddha image with the right shoulder and right thigh bigger than the left}

Dated around the $19-20^{\text {th }}$ Buddhist century, the Chiang Saen school became dominant in northern Thailand, especially in Chiang Mai province. This school was influenced by both Sukhothai art and the Pala Indian school through Burma. Buddha images were largely made of bronze. The base, measuring about 1-2 feet, was inscribed with the year of creation and the purpose, such as, to give merit to parents, grandparents, and the creator, so that they would attain three levels of bliss - which are human bliss, heavenly bliss, and Nirvana. 


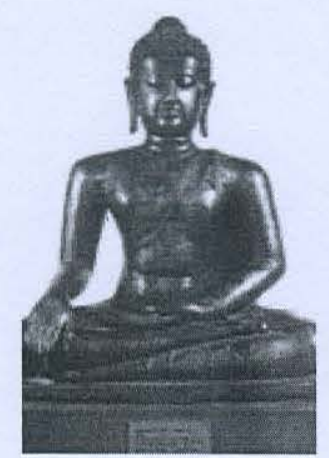

\section{The Chiang Saen school}

The Chiang Saen Buddha image owed its body proportions to the Sri Lankan school through Nakorn Sri Thammarat in southern Thailand. The chest of the Buddha was as prominent as a lion's. The length from the chest to the arms and from the chest to the thighs must also be equal. In this way, the Buddha image is said to be like a newborn baby, which signifies purity and perfection.

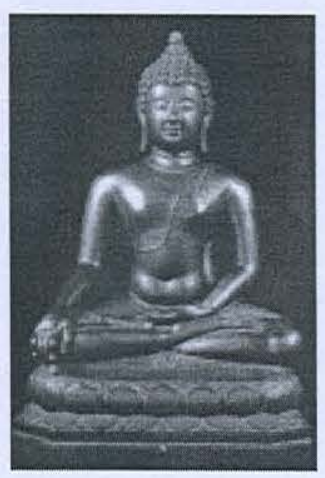

\section{The Buddha was as prominent as a lion}

In addition, Buddha images also appeared in a seated position. The image, wearing a diadem, has a bare chest decorated with jewelry. Its waist is concave, giving a space between the waist and the left arm. The image signifies the Bodhisattva Maitreya, the
Buddha who is predicted to appear in the future.

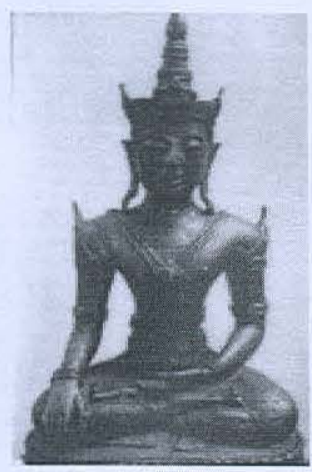

\section{The bodhisattva Maitreya, Chiang Saen school}

As Thailand's northern region is close to China, Chiang Saen Buddha images were inevitably influenced by Chinese art. The Buddha appears with a lotusshaped base - a typical Chinese tradition - and a hexagonal base in the shape of a bat's wings, signifying prosperity. The Buddha's eyes are decorated with sapphire and mother-of-pearl; the body is painted in red and covered with gold leaf. To decorate the eyes, there must be an eye-opening ceremony, and the only person who can open the Buddha's eyes is the one who has commissioned it, not the sculptor. It was believed that such a ceremony would make the image come to life. 

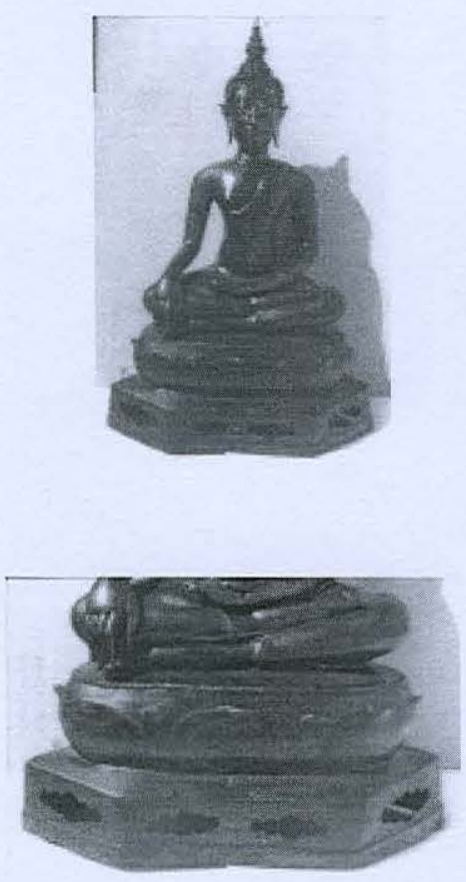

Chiang Saen - in typical Chinese tradition, with a hexagonal base in the shape of a bat's wings

Ayutthaya School $\left(18-23^{\text {rd }}\right.$ Buddhist centuries)

The initial phase is called U Thong art, which coincided with Sukhothai and Chiang Saen art. U Thong Buddha images were mostly found in the central region of Thailand, which had been influenced by the Dvaravati and Lopburi schools due to political reasons. With Thai people migrating from the North, the U Thong school was blended with Sukhothai. The result is the unique Ayutthaya Buddha art.

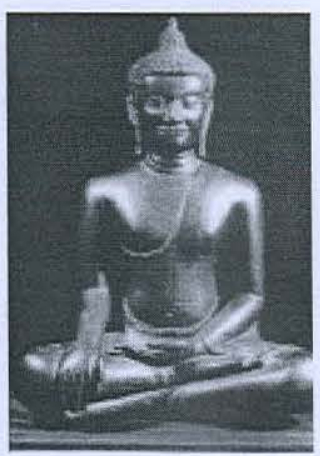

\section{The U Thong - Ayuthaya school}

In the early stage, the Buddha images of the U Thong-Ayutthaya school were different from those of other schools, with lotus-bud aureole like the wings of a bird, and small pointed hair curls like the thorns of a jackfruit, a more humanlike face and a cleft lower chin.

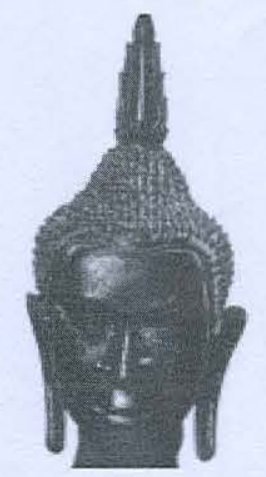

The lotus-bud aureole like the wings of a bird 


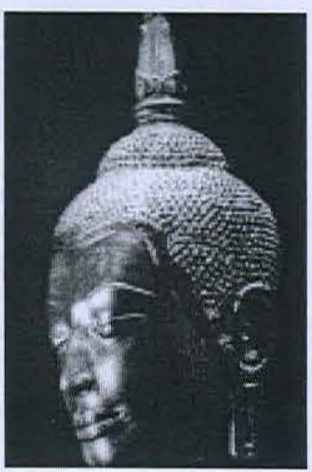

\section{Small pointed hair curls like the thorns of a jackfruit, a more humanlike face and a eleft lower chin}

U-Thong artists had developed a casting procedure using very thin bronze, which allowed them to save metal. Presumably, this was because part of the bronze was being used in the forging of swords, to get ready for the war of liberation against the Khmer.

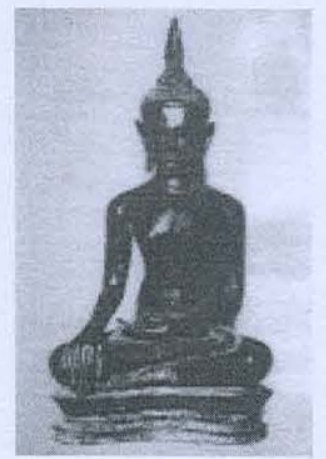

\section{U thong Buddha image}

In the middle and final periods, the kingdom became wealthy from successful trade with China and India. Ayutthaya exported rice to and imported copper from China, and precious stones from India. Therefore, the Buddha image of this period was seen wearing royal attire, which included a hair band, necklaces, bracelets, and sashes of gold and gemstones.

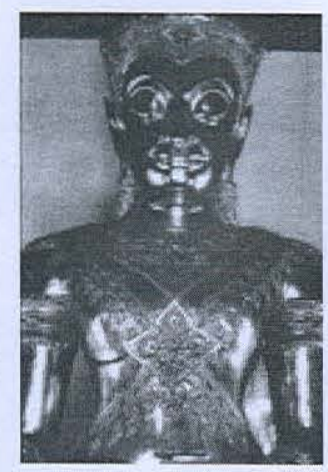

\section{Buddha image wearing royal attire}

The Buddha standing upright, with both palms raised is known as "Stopping the Ocean" posture. The image also has on footwear. This one is believed to have been commissioned by an Ayutthaya king. Turning to another image with few decorations and short lotusbud aureole, the Buddha is depicted as standing with his right hand raised to the chest level and the left arm falling to the side. He is not wearing any footwear. This posture is known as "Stopping relatives from fighting." The icon is said to have been commissioned by a queen.

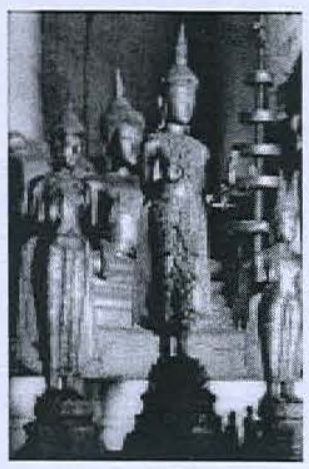

\section{Stopping the Ocean posture}




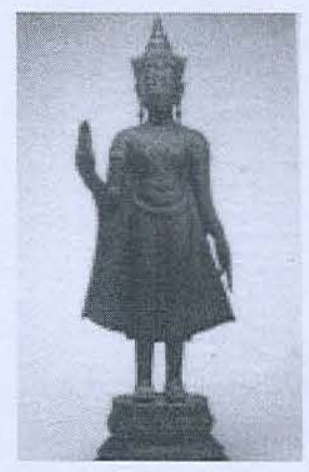

\section{Stopping relatives from fighting}

The Buddha image in royal attire was largely the influence of the Pala Indian school. In Mahayana tradition, such a richly-decorated image refers to the Ahthit Buddhachao. But Ayutthaya, which essentially adopted Theravada Buddhism, viewed it either as the Buddha Sakyamuni or as the representation of a former king. Another assumption is that the image represents the creator himself, who wanted to make merit so that he could become a Buddha in a future life.

Ayutthaya was dominated by the Mahapurisa Laksana tradition from Sri Lanka through Thailand's southern Nakorn Sri Thammarat province. The remarkable characteristics include the lion-like chest, which must be rounded in symmetrical fashion, and the four fingers of both hands of equal length.

The Rattankosin school can be dated from the $23^{\text {rd }}$ century to present. After the Ayutthaya kingdom fell to the Burmese invasion, Thai people subsequently moved to set up their new capital in Bangkok. In the early phase, the creation of new Buddha images was not popular; most Buddhists just attempted to repair the damaged Buddha images in ruined cities such as Sukhothai and Ayutthaya.
The sculpting of Buddha images was most popular in the reign of King Rama III, who himself commissioned the largest number of Buddha images created in history. In addition to traditional postures, the king also decreed the casting of 34 bronze images of the Buddha in new postures, as a tribute to the 34 former monarchs of Ayutthaya.
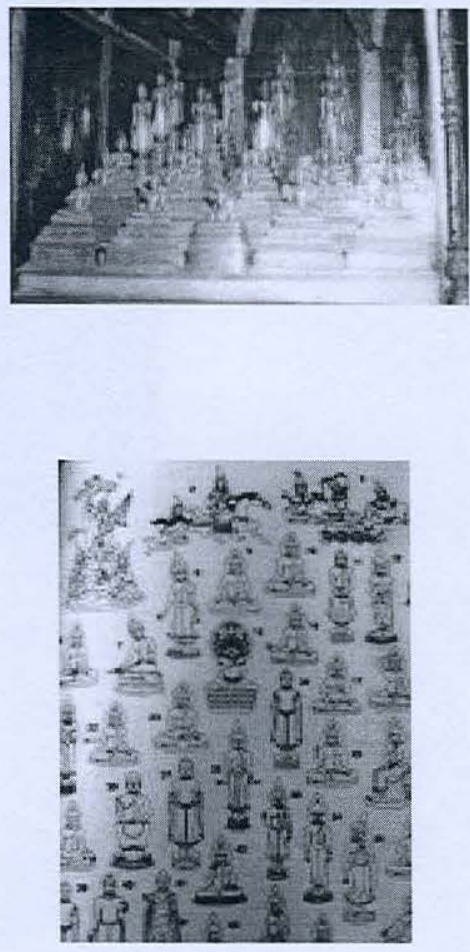

\section{Bronze images}

All the 34 newly identified poses were selected from a number of episodes in the life of the Buddha. King Rama III seemed to favor a realistic type of Buddha image. For example, the "Buddha sheltered by Naga" posture featured the Buddha fully enveloped by the Naga's body, with only the Buddha's head protruding. This all too realistic portrayal may cause aesthetic value to be lost. 


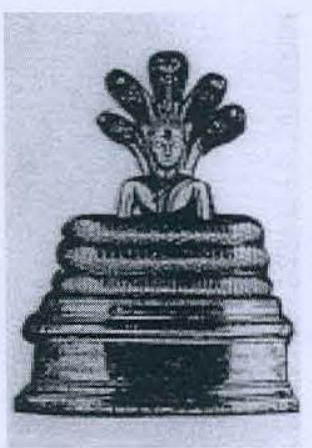

The Buddha sheltered by a Naga, fully enveloped by the Naga's body

The Ayutthaya tradition of a richly decorated Buddha image was also adopted in the Rattanakosin era. But large Buddha images no longer bear evidence of the proposed representation, that is, allowing the creator monarch to become the Buddha incarnate. However, when King Rama III then created two heavily adorned Buddha images, and placed the ashes of his father and grandfather inside the topknot of the images, the assumption was confirmed that with the Buddha image in royal attire the Ayutthaya King considered himself to represent the Buddha.

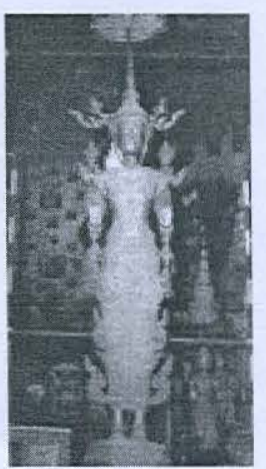

The Rattanakosin image in royal attire
Though some traditions in the Sri Lankan Mahapurisa Laksana text, such as, that the Buddha's four fingers of both hands must be of equal length, were still followed, local artists turned to their Thai aesthetic heritage handed down from the Sukhothai era. This can be seen from the tradition that the Buddha's eyes be like those of a soaring bird, and the body proportion be pre-determined. For instance, the body of the Buddha in royal attire must be seven times longer than the head; the body of the standing Buddha must be only six times longer; otherwise, aesthetic value would be lost. Such norms have been observed since ancient times - deviation from this would result in a dwarfish image deprived of beauty and grace.
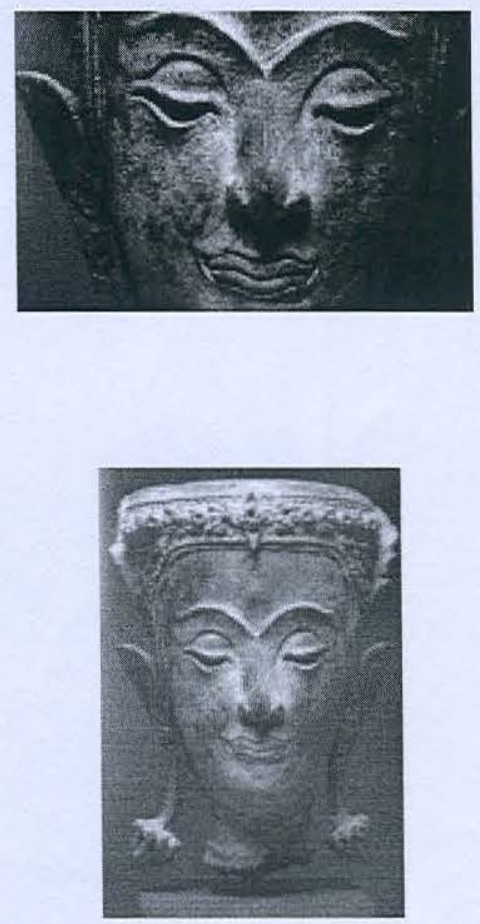

Eyes like air passing a soaring bird 


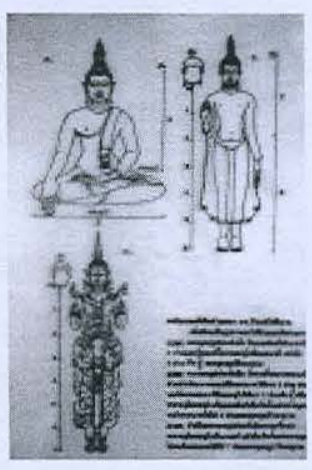

The Buddha in royal attire must be seven times longer, the body of the standing Buddha must be only six times longer

That was the beauty of the Buddha images in the eyes of one sculptor, who has been studying images ranging from two feet to life-size. In Thailand there are larger images of the Buddha - from life-size to gigantic - which are being housed in Viharas or Chapels. But the life-size or slightly bigger ones are usually placed at the temple gallery.

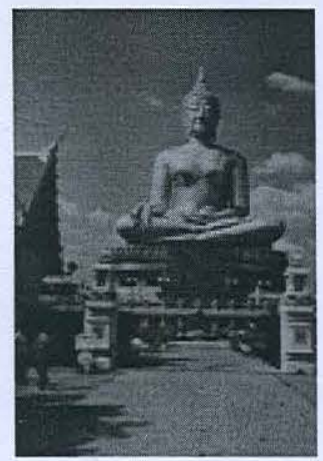

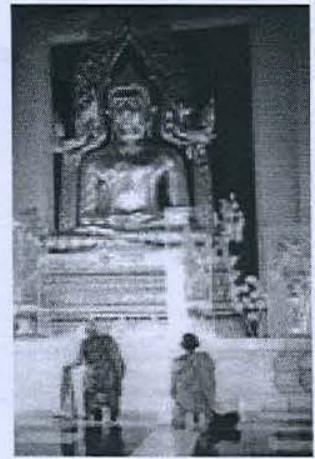

The gigantic Buddha image

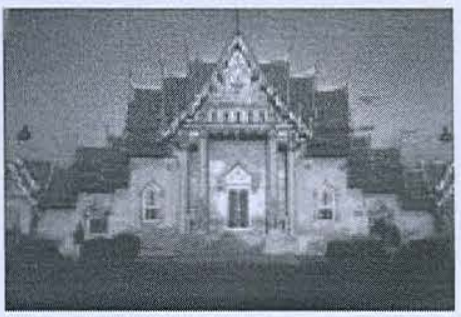

Vihara or Chapel

These Buddha images were made of either bronze, or mortar, or stucco. The most popular pose is the "Buddha Subduing Mara", as Thai people believe the Enlightenment was the most important event in the Buddha's life. This is different from the Chinese tradition, which was based on Mahayana Buddhism. Taking a look at temples in Chinese communities, you will find a larger variety of poses of Buddha, a stark contrast to the Thai temples of Theravada Buddhism. Most Buddha images found at Chinese temples are in seated or standing positions; only the hands differ from the Thai style, with five gestures as follows: 
1. The Heart of the Buddha

2. The Triple Gem

3. Giving of Holy Water

4. Resolute in his Perfection

5. Morality and Patience

The Buddha with the five gestures is the Nyorai.
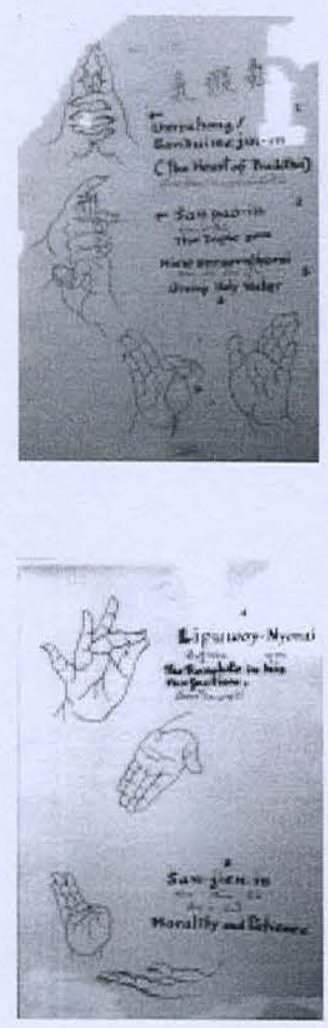

Undoubtedly, these Buddha images were indicative of the ethnicity of their creators, who all wished the Enlightened One to reflect features of their countrymen.

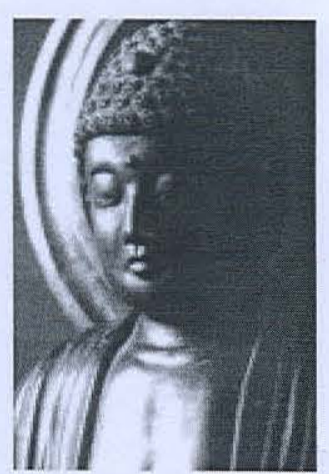

The Buddha images were indicative of the ethnicity of their creators

However, the Buddha artistic schools in Thailand have their own varieties according to region and locality. For example, the Haripunchai School in northern Thailand was influenced by Dvaravati and Lopburi, which Sukhothai and Chiang Saen had adopted and applied to create their own style. There is the Isaan school from the Northeast, which is characterized by the Buddha's small eyes and the aureole in the shape of bamboo shoots - $\mathrm{a}$ favorite food of Northeasterners. Bamboo represents fertility. There is also Nakorn Sri Thammarat, the school of the South, which was the first to apply the symmetrical fashion - a direct influence from Sri Lanka - to the image. Its outstanding and unique creation was called "Phra Buddha Sihing." The word was derived from "Phra Singha" or the "Lion Lord," meaning the lion-like Buddha. 


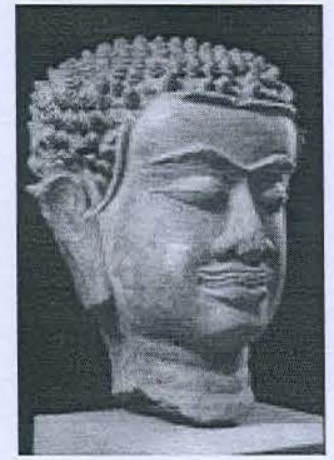

\section{The Haripunchai School}
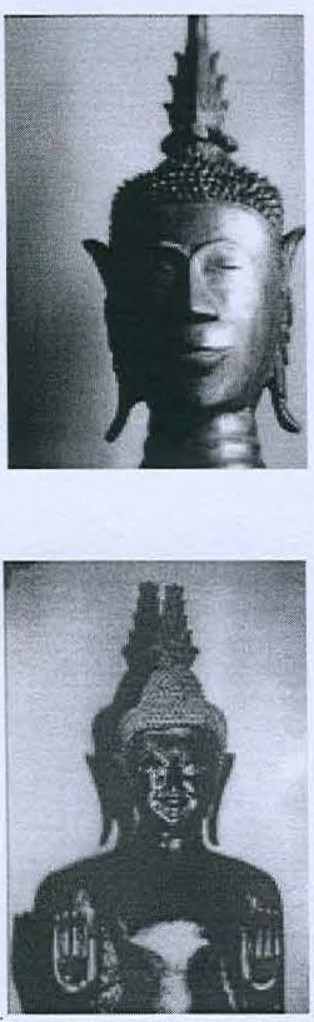

The Isaan School

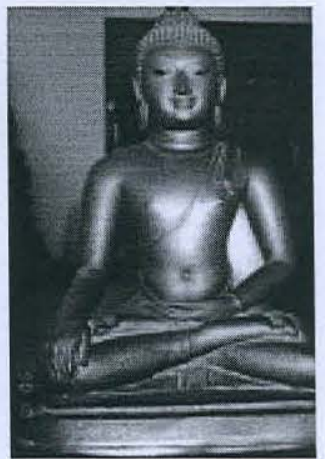

\section{The Nakorn Sri thammarat school}

The Buddhist artistic styles I have talked about are indicative of origin, development, cultural current, influence, impact, and ethnicity. All of these bring about a sense of proportion and beauty that is unique, thus adding an aesthetic dimension to its simply being an object of reverence.

\section{GLOSSARY}

Amitabha - The Buddha, Lord of the Western Pure Land or Paradise.

Avalokitesvara - The "Lord who looks down upon the world" (with pity). In Mahayana Buddhism, the bodhisattva who embodies the quality of compassion. $\mathrm{He}$ is an attendant to the Buddha of the western paradise, an image of whom appears on his headdress.

Bodhisattva- "Enlightenment being," an eventual Buddha. The historical Buddha Sakyamuni in his previous existences. In Mahayana Buddhism, a celestial being who has voluntarily renounced Buddhahood until all creatures can reach the ultimate state together. Bodhisattvas exemplify virtues and are depicted as if they were princes. 
Buddhist era - The era beginning in 543 or $544 \mathrm{BC}$, the traditional date of the Buddha Sakyamuni's passing away.

Mahayana Buddhism - "Great-vehicle" Buddhism. The Buddhism that developed in the early centuries of our era, based on texts that had only recently come to light but were considered to have been taught by Sakyamuni. Mahayana Buddhists tend to believe in Buddha paradises and to follow the Bodhisattva path (the doctrine that beings should forego entry into nirvana until all creatures can enter together).

Mahapurisa - The name given to a Great Being. He carries on his person the following thirty-two marks. 1. he has feet of level tread; 2. on his soles are marks of wheels with spokes, felloes and hubs; 3 . his heels project; 4 . his digits are long; 5 . his hands and feet are soft; 6 . his fingers and toes straight; 7 . his ankles like rounded shells; 8 . his legs like an antelope's; 9. standing, he can touch his knees without bending; 10. his private parts are within a sheath; 11 . he is of golden hue; 12 . his skin is so smooth that no dust clings to it; 13 . the down on his body forms single hairs; 14 . each hair is straight, blue black and at the top curls to the right; 15 . his frame is straight; 16 . his body has seven convex surfaces; 17 . his chest is like a lion's; 18 . his back is flat between the shoulders; 19 . his sheath is the same as his height; 20 . his bust is equally rounded; 21 .his taste is consummate; 22 . he has a lion's jaws; 23 . has forty teeth; 24 . they are regular, 25. and continuous; 26. lustrous; 27 . his tongue is long; 28. his voice like that of a karavika bird; 29 . his eyes intensely black; 30 .

his eyelashes like a cow's; 31 . between his eyelashes are soft, white hairs like cotton down; 32 . his head is like a turban. The theory of Mahapurisa is pre Buddhistic. Several passages in the Pitakas mention Brahmins as claiming that this theory of the Mahapurisa and his natal marks belonged to their stock of hereditary knowledge. The Buddhists, evidently, merely adopted the Brahmin tradition in this matter as in so many others. But they went further. In the Lakkhana Sutta they sought to explain how these marks arose, and maintained that they were due entirely to good deeds done in a former birth and could only be continued in the present life by means of goodness. Thus the marks are merely incidental; most of them are so absurd, considered as the marks of a human being, that they are probably mythological in origin, and a few of them seem to belong to solar myths, being adaptations to a man, of poetical epithets applied to the sun or even to the personification of human sacrifice. Some are characteristic of human beauty, and one or two may possibly be reminiscences of personal bodily peculiarities possessed by some great man, such as Gotama himself.

Maitreya - The Buddha of the future, who now dwells in the Tusita heaven. As a Mahayana bodhisattva, he is depicted as a prince with a small stupa as ornament on his headdress. $\mathrm{He}$ is sometimes paired with Avalokitesvara.

Mantle - (Sanghati.) Sometimes called a shawl. One of the three principal 
elements of the dress of the Buddha or of a monk (the others being the undergarment and the robe). Identical to the robe in dimensions, it is frequently worn folded and pleated, hanging over the wearer's left shoulder. In sculpture, the dimensions of the folded mantle are minimized.

Naga - Mythical reptile or serpent. In Thailand and Cambodia, the Indian naga has many of the fecund qualities of the Chinese dragon.

Naga-protected Buddha - (Thai nakprok, "a naga sheltering".) Buddha seated on the coils of the naga, whose multiple heads are seen above the Buddha's. The iconic type is based on an episode that took place shortly after the enlightenment, when the spirit of a pond sheltered the Buddha from a rainstorm.

Sihing- Name of the Buddha image that, according to legend, arrived in peninsular Thailand from Sri Lanka in the thirteenth century. It was later the model for an important type of icon, especially in the Chiang Saen school. (The name was derived from Sanskrit simha, "lion," or Simhala, "Sri Lanka," land of the descendants of Simhala the lionkiller.)

Theravada Buddhism - the "way of the elders." the Buddhism practiced in Sri Lanka, Burma, and Thailand, based upon scriptures and commentaries in the Pali language.

Unalom - A curlicue-like design placed at the top of magical diagrams, it is the central element in the ketumala crowning the Buddha's head in
Sukhothai and other images. (Una from Sanskrit urna; loma means "body hair.")

U Thong - Thao U Thong ("Prince Golden Cradle") was a figure of legend who became the first king of Ayutthaya in 1351. His name has become the name of a place ( $\mathrm{U}$ Thong, meaning the town from which the prince came) and of an art style thought to have been prevalent in the mid-fourteenth century, in which lingering Cambodian elements are present. 